\title{
Associations between strain, herd size, age at first calving, culling reason and lifetime performance characteristics in Holstein-Friesian cows
}

\author{
K. Adamczyk ${ }^{1 \dagger}$, J. Makulska ${ }^{1}$, W. Jagusiak ${ }^{2}$ and A. Węglarz ${ }^{1}$ \\ ${ }^{1}$ Department of Cattle Breeding, Institute of Animal Sciences, University of Agriculture in Krakow, Al. Mickiewicza 24/28, 30-059 Krakow, Poland; ${ }^{2}$ Department of \\ Genetics and Animal Breeding, University of Agriculture in Krakow, Al. Mickiewicza 24/28, 30-059 Krakow, Poland
}

(Received 5 February 2016; Accepted 5 June 2016; First published online 13 July 2016)

Cow longevity and lifetime performance traits are good indicators of breeding effectiveness and animal welfare. They are also interrelated with the economics of dairy herd. Unfortunately, a high milk yield is often associated with deteriorated cow health and fertility and, consequently, with an increased culling rate. This situation, observed also in the Polish population of Holstein-Friesian cattle, inspired us to undertake a study on the associations between some factors and lifetime performance characteristics. The data set consisted of the records on 135496 cows, including 131526 of the Black and White strain (BW), and 3970 of the Red and White strain (RW) covered by performance recording and culled in 2012. It was found that cows of the BW strain and those from the largest herds (>100 cows) reached higher lifetime and mean daily energy-corrected milk (ECM) yields than cows of the RW strain and those from smaller herds culled at a similar age. Cows youngest at first calving ( $<2.0$ years) were characterised by the highest lifetime ECM yield. It indicates that heifers can be bred even when they are younger than 15 to 16 months with no significant negative effect on their later performance. Infertility and reproduction problems (39.6\%) and udder diseases (15.5\%) constituted the most frequent reasons for cow culling. Cow longevity and lifetime productivity were considerably affected by the interactions between the studied factors.

Keywords: Holstein-Friesian strains, cow use intensity, longevity, lifetime milk production, culling reason

\section{Implications}

The present study estimated the associations between the strain, herd size, age at first calving and the culling reason as well as interactions between them on lifetime performance characteristics of high-yielding Holstein-Friesian (HF) cows. The obtained results contribute to a better insight into significance of the analysed factors for the efficient management of a dairy herd and, consequently, to the enhanced profitability of milk production.

\section{Introduction}

Cow lifetime performance characteristics may include length of productive life, number of lactations, number of lifetime milking days, lifetime productivity and mean lifetime productivity in a certain period of time, for example, per day (Sawa and Krężel-Czopek, 2009; Ahlman et al., 2011; Heinrichs and Heinrichs, 2011). The aforementioned

\footnotetext{
† E-mail: rzadamcz@cyfronet.pl
}

indicators are to a large extent complementary and their combined use provides a comprehensive evaluation of lifetime dairy performance.

The long-term selection for milk yield and the intensive use of cows resulted in an admittedly high growth of milk yield but also in the increased frequency of early involuntary culling, which can be attributed to poor animal welfare (Oltenacu and Broom, 2010; Thornton, 2010; Ahlman et al., 2011). To address this problem, parallel activities in breeding practice and in herd management have been introduced. The former consist mainly in raising the importance of functional traits in selection indexes for HF cattle (e.g. since 2014, the weight of these traits in the Polish selection Index Production and Functionality, is 60\%) and the latter in improving the environmental conditions for dairy cattle (Oltenacu and Broom, 2010; Zavadilová and Zink, 2013; Polish Federation of Cattle Breeders and Dairy Farmers in Warsaw (PFCBDF), 2015). The increasingly common selection for the so-called functional longevity, understood as the true longevity corrected for milk yield, should result in more robust cows well adapted to diverse living conditions 
(Pritchard et al., 2013; Zavadilová and Zink, 2013). However a direct way to extend the lifetime of high-yielding cows is to ensure them proper welfare. A growing attention not only to functional traits and animal welfare, but also to direct environmental impact of dairy production (e.g. greenhouse gas emission) complies with the widely promoted idea of so-called sustainable farming (Axelsson, 2013). Unfortunately, it often entails additional expenditure, negatively affecting the economic result, which is the main purpose of the production practice. On the other hand, under improved welfare conditions, resulting in the extended productive life, the need for replacement heifers is decreased. The reduced replacement cost raises overall profitability. Moreover, better welfare and a less intensive use of cows may also lead to the improved quality of the product obtained, which in turn contributes to higher revenue from milk production (Hadley et al., 2006; Ahlman et al., 2011; De Vries, 2013). Thus finding the optimal level of production intensity seems to be one of the key elements for the economic efficiency of dairy operations.

Since HF cattle are the most numerous dairy breed used all over the world, the aforementioned problems have a global and universal character (Miglior et al., 2005; Oltenacu and Broom, 2010; Thornton, 2010). In Poland, HF cows account for as much as $90 \%$ of dairy cows covered by milk recording, of which the Black and White strain (BW) represents $94 \%$ and the Red and White strain (RW) the remaining 6\% (PFCBDF, 2015). In 2014, the mean milk yield of BW and RW cows amounted, respectively, to 7742 and $7068 \mathrm{~kg} / 305$ days lactation, which does not indicate their very intensive use. The mean productive life length (i.e. mean number of days from first calving to culling) of HF cows in Poland amounts to only 3.2 years. A short longevity is an important problem, especially in high-yielding dairy herds (PFCBDF, 2015).

This inspired us to undertake a study aimed at getting an insight into the possible associations between the strain, herd size, age at first calving and the culling reason of Polish HF cows and their lifetime performance characteristics.

\section{Material and methods}

\section{Animals}

The data analysed, acquired from the SYMLEK Polish National Milk Recording System, concerned 135496 Polish HF cows (131526 of the BW strain and 3970 of the RW strain), which represented about $94 \%$ of the total number of dairy cows culled in Poland in 2012. The minimum percentage of $\mathrm{HF}$ genes was $93.75 \%$.

\section{Data editing}

The final data set was obtained by excluding the records of cows calved for the first time at the age of $<580$ or $>1464$ days, cows with a mean milk yield $<5 \mathrm{~kg}$, cows with 100 milking days or more and the fat content outside $2 \%$ to $9 \%$ range and the protein content outside $2 \%$ to $7 \%$ range as well as cows with $<100$ milking days and the fat content outside $1.5 \%$ to $9 \%$ range and the protein content outside $1 \%$ to $7 \%$ range. The above-mentioned treatments were in compliance with International Committee for Animal Recording (2012) principles.

The analysed data included the average number of cows per herd, the age at first calving, the age at culling, the lifetime number of days in milk, the lifetime milk yield, the mean lifetime fat and protein contents of milk and the culling reason.

The following traits were assumed as lifetime performance characteristics: age at culling, lifetime energy-corrected milk yield (LECM) and the mean lifetime energy-corrected milk yield per milking day (DECM).

LECM was computed according to the formula of Sjaunja et al. (1990):

$$
\mathrm{LECM}=\mathrm{M} \times(383 \times \mathrm{MF}+242 \times \mathrm{MP}+783.2) / 3140
$$

where LECM is the lifetime energy-corrected milk yield $(\mathrm{kg})$, $\mathrm{M}$ the lifetime milk yield $(\mathrm{kg})$, MF the mean lifetime milk fat content (\%) and MP the mean lifetime milk protein content (\%).

DECM was computed according to the above formula modified as follows:

$$
\mathrm{DECM}=(\mathrm{M} / \mathrm{MD}) \times(383 \times \mathrm{MF}+242 \times \mathrm{MP}+783.2) / 3140
$$

where $D E C M$ is the mean lifetime energy-corrected milk yield per milking day $(\mathrm{kg}), \mathrm{M}$ the lifetime milk yield $(\mathrm{kg}), \mathrm{MD}$ the number of milking days, MF the mean lifetime milk fat content (\%) and MP the mean lifetime milk protein content (\%).

\section{Statistical analysis}

Data were analysed by means of the SAS GLM procedure (SAS Institute Inc., 2008). The significance of the main effects and interactions were validated by test $F$, and then differences between the means were verified using the Sheffe's test. The following linear model was applied:

$$
\begin{aligned}
Y_{i j k l m}=\mu & +G_{i}+H_{j}+A_{k}+C_{l}+(G H)_{i j}+(G A)_{i k}+(G C)_{i l} \\
& +(H A)_{j k}+(H C)_{j l}+(A C)_{k l}+G_{i j k l m}
\end{aligned}
$$

where $Y_{i j k l m}$ is the observation (age at culling or LECM or DECM), $\mu$ the overall mean, $G_{i}$ the effect of ith strain (RW, BW), $H_{j}$ the effect of $j$ th herd size ( $<50$ cows; 50 to 100 cows; $>100$ cows), $A_{k}$ the effect of $k$ th age at first calving $(<2.0$ years; 2.0 to 2.6 years; $>2.6$ years), $C_{\text {, the effect of } / \text { th culling }}$ reason (old age, low milk yield, infertility and reproduction problems, udder diseases, leg diseases, nutritive and metabolic diseases, respiratory system diseases, infectious diseases, accidents, other) and effects of interactions: $(G H)_{i j}$ is the strain by herd, $(G A)_{i k}$ the strain by age at first calving, $\left(G C_{i l}\right.$ the strain by culling reason, $(H A)_{j k}$ the herd by age at first calving, $(H C)_{j l}$ the herd by culling reason, $(A C)_{k l}$ the age at first calving by culling reason and $\epsilon_{i j k l m}$ the random error.

Herd size classes were determined by analysing the herd size distribution in Poland (PFCBDF, 2015). Classes of age at first calving were distinguished based on the mean and the standard deviation. Cows whose calving age was lower than 
the mean - SD were assigned to the first class, the second class was defined for cows calving at the age of the mean \pm SD and the third class for cows calving later than the mean + SD. Culling reasons were defined according to the terminology used in the cow performance recording system by the Polish Federation of Cattle Breeders and Dairy Farmers.

\section{Results}

The mean age at culling did not exceed 6 years and was similar for both HF varieties (Table 1). Cows of the BW strain had a significantly higher LECM $(P=0.0028)$ and DECM $(P=0.0190)$ compared with cows of the RW strain, but generally, the lifetime performance of both cow groups studied was not very high. It was found that while the age at culling was only slightly affected by the herd size, LECM and DECM increased significantly $(P=0.0001$ to 0.0093 and $P=0.0001$, respectively) with the increase of the herd size. The differences between the biggest and the smallest herds amounted to $3671 \mathrm{~kg}$ of LECM and $3.7 \mathrm{~kg}$ of DECM. The age at culling was positively, though insignificantly, associated with the age at first calving. The cows from the third class of the age at first calving achieved the lowest LECM of $20783 \mathrm{~kg}$ and DECM of $19.7 \mathrm{~kg}$, and these values differed significantly $(P=0.0001)$ from those of cows calved first at an earlier age.

The mean culling age of cows disposed of due to their age (9.5 years) was nearly twice as high and LECM $(50039 \mathrm{~kg})$ was more than twice as high as of those culled due to all other reasons (4.2 to 5.6 years) (Table 2). It means that the productive life length of cows disposed of for other reasons only slightly exceeded the length of the period from their birth to first calving. The most common reasons of involuntary cullings consisted in the infertility and reproduction problems as well as udder diseases $(39.6 \%$ and $15.5 \%$, respectively). Cows culled because of infectious diseases and low milk yield had the lowest LECM (15972 and $17260 \mathrm{~kg}$, respectively). However, both reasons accounted for only slightly $>2 \%$ of all cullings.

The association between the strain $\times$ herd size subclasses and lifetime performance characteristics is presented in Table 3. As many as $82 \%$ of BW and $78 \%$ of RW culled cows came from either the smallest or the largest herds. The oldest age at culling was found in BW cows from the smallest herds and this value differed significantly $(P=0.0063)$ from the earliest age at culling which was observed in RW cows maintained in the smallest herds as well. The differences in the age at culling between cows from various strain $\times$ herd size classes were more significant for the BW than the RW strain. Numerous significant differences between LECM $(P=0.0001$ to 0.0286$)$ and $\mathrm{DECM}(P=0.0001$ to 0.0218$)$ indicated a strong strain $\times$ herd size interaction. The highest LECM and DECM was found for BW cows in the largest herds. Both BW and RW cows gave less milk in the smallest herds (DECM 18.9 and $18.4 \mathrm{~kg}$, respectively) than in the largest herds (DECM 23.1 and $21.6 \mathrm{~kg}$, respectively). The lowest LECM was observed in the smallest herds, independently from the cow strain. The differences between the highest and the lowest value of DECM within a particular strain amounted to $22 \%$ for BW and $17 \%$ for RW. The differences in LECM were $7 \%$ and $31 \%$, respectively, due to a lower daily milk yield in cows with higher age at culling.

The association between the strain and the age at first calving had a considerable impact on longevity characteristics, but significant differences $(P=0.0001$ to 0.0132$)$ were found only for the age at culling, mainly in the BW strain (Table 4). It is worth emphasising that while the difference between the highest and the lowest values of DECM amounted only to $9 \%$, in the case of LECM it reached $45 \%$.

Table 1 Associations between strain, herd size, cows' age at first calving and lifetime performance characteristics

\begin{tabular}{|c|c|c|c|c|}
\hline & & Age at culling (years) & LECM (kg) & DECM (kg/day) \\
\hline Effects & $n$ & $\mathrm{LSM} \pm \mathrm{SE}$ & $\mathrm{LSM} \pm \mathrm{SE}$ & $\mathrm{LSM} \pm \mathrm{SE}$ \\
\hline \multicolumn{5}{|l|}{ Strain } \\
\hline Black and white & 131526 & $5.8 \pm 0.1$ & $25337^{A} \pm 205.0$ & $20.8^{a} \pm 0.1$ \\
\hline Red and white & 3970 & $5.4 \pm 0.2$ & $21566^{A} \pm 1246.8$ & $19.9^{\mathrm{a}} \pm 0.4$ \\
\hline \multicolumn{5}{|l|}{ Herd size (head) } \\
\hline$<50$ & 67762 & $5.6 \pm 0.1$ & $21561^{\mathrm{AB}} \pm 697.2$ & $18.6^{\mathrm{AB}} \pm 0.2$ \\
\hline 50 to 100 & 24498 & $5.7 \pm 0.1$ & $23561^{\mathrm{AC}} \pm 706.4$ & $20.0^{\mathrm{AC}} \pm 0.2$ \\
\hline$>100$ & 43236 & $5.5 \pm 0.1$ & $25232^{B C} \pm 698.2$ & $22.3^{\mathrm{BC}} \pm 0.2$ \\
\hline \multicolumn{5}{|c|}{ Age at first calving (years) } \\
\hline$<2.0$ & 25605 & $5.4 \pm 0.1$ & $25184^{A} \pm 720.6$ & $20.5^{A} \pm 0.2$ \\
\hline 2.0 to 2.6 & 93101 & $5.6 \pm 0.1$ & $24387^{B} \pm 635.8$ & $20.7^{\mathrm{B}} \pm 0.2$ \\
\hline$>2.6$ & 16790 & $5.9 \pm 0.1$ & $20783^{\mathrm{AB}} \pm 799.5$ & $19.7^{\mathrm{AB}} \pm 0.2$ \\
\hline
\end{tabular}

LECM = lifetime energy-corrected milk yield; DECM = mean lifetime energy-corrected milk yield per milking day; LSM = least square mean.

Herd size varied from 2 to 1075 cows. Age at first calving varied from 1.6 to 4.0 years.

${ }^{a}$ Values within a column, within each effect, with the same superscripts differ significantly at $P<0.05$.

$A, B, C$ Values within a column, within each effect, with the same superscripts differ significantly at $P<0.01$. 
Adamczyk, Makulska, Jagusiak and Węglarz

Table 2 Association between cow culling reason and lifetime performance characteristics

\begin{tabular}{|c|c|c|c|c|}
\hline & & Age at culling (years) & LECM $(\mathrm{kg})$ & DECM (kg/day) \\
\hline Culling reasons & $n$ & $\mathrm{LSM} \pm \mathrm{SE}$ & $\mathrm{LSM} \pm \mathrm{SE}$ & $\mathrm{LSM} \pm \mathrm{SE}$ \\
\hline Old age & 2347 & $9.5^{\text {ADEHKLMNO }} \pm 0.1$ & $50039^{\text {AFGHKLMNO }} \pm 1031.7$ & $19.4^{\mathrm{a}} \pm 0.3$ \\
\hline Low milk yield & 3053 & $4.9^{\mathrm{BCDa}} \pm 0.1$ & $17260^{\mathrm{BCDEF}} \pm 737.8$ & $17.7^{\mathrm{ABCDEFGa}} \pm 0.2$ \\
\hline Infertility and reproduction problems & 53593 & $5.6^{\mathrm{CIJK}} \pm 0.1$ & $23354^{\text {DIJKa }} \pm 234.3$ & $19.9^{\mathrm{CH}} \pm 0.1$ \\
\hline Udder diseases & 21013 & $5.6^{\mathrm{BFGH}} \pm 0.1$ & $22764^{\mathrm{CHb}} \pm 334.6$ & $19.9^{B} \pm 0.1$ \\
\hline Legs diseases & 14157 & $5.4^{\mathrm{Ma}} \pm 0.1$ & $22450^{\mathrm{EM}} \pm 400.2$ & $20.5^{\mathrm{EHb}} \pm 0.1$ \\
\hline Nutritive and metabolic diseases & 10662 & $5.1^{\mathrm{GJN}} \pm 0.1$ & $20129^{\mathrm{JNb}} \pm 518.1$ & $20.3^{\mathrm{F}} \pm 0.2$ \\
\hline Respiratory system diseases & 904 & $5.2^{0} \pm 0.3$ & $20719^{\circ} \pm 1861.3$ & $21.0^{\mathrm{G}} \pm 0.6$ \\
\hline Infectious diseases & 159 & $4.2^{\mathrm{A}} \pm 0.8$ & $15972^{A} \pm 5773.8$ & $24.5 \pm 1.8$ \\
\hline Accidents & 16789 & $5.2^{\mathrm{FIL}} \pm 0.1$ & $20628^{1 \mathrm{~L}} \pm 428.4$ & $20.2^{D} \pm 0.1$ \\
\hline Other & 12819 & $5.3^{\mathrm{E}} \pm 0.1$ & $21201^{\mathrm{BGa}} \pm 427.2$ & $19.8^{\mathrm{Ab}} \pm 0.1$ \\
\hline
\end{tabular}

LECM = lifetime energy-corrected milk yield; DECM = mean lifetime energy-corrected milk yield per milking day; LSM = least square mean.

${ }^{a, b}$ Values within a column, with the same superscripts differ significantly at $P<0.05$.

$A, B, C, D, E, F, G, H, I, J, K, L, M, N, O$ Values within a column, with the same superscripts differ significantly at $P<0.01$.

Table 3 Association between strain $\times$ herd size and lifetime performance characteristics of the cows

\begin{tabular}{|c|c|c|c|c|}
\hline & & Age at culling (years) & LECM (kg) & DECM (kg/day) \\
\hline Strain $\times$ herd size & $n$ & $\mathrm{LSM} \pm \mathrm{SE}$ & $\mathrm{LSM} \pm \mathrm{SE}$ & $\mathrm{LSM} \pm \mathrm{SE}$ \\
\hline Black and White $\times$ below 50 cows & 66098 & $6.0^{\mathrm{AB}} \pm 0.1$ & $24411^{\mathrm{AB}} \pm 275.9$ & $18.9^{\mathrm{ABC}} \pm 0.1$ \\
\hline Black and White $\times$ from 50 to 100 cows & 23614 & $5.8^{C} \pm 0.1$ & $25580^{C} \pm 395.6$ & $20.4^{\mathrm{ADE}} \pm 0.1$ \\
\hline Black and White $\times$ above 100 cows & 41814 & $5.5^{\mathrm{AC}} \pm 0.1$ & $26018^{\mathrm{ADa}} \pm 269.1$ & $23.1^{\mathrm{BDFGa}} \pm 0.1$ \\
\hline Red and White $\times$ below 50 cows & 1664 & $5.3^{B} \pm 0.2$ & $18710^{\mathrm{BCDEb}} \pm 1320.4$ & $18.4^{\mathrm{EFHI}} \pm 0.4$ \\
\hline Red and White $\times$ from 50 to 100 cows & 884 & $5.5 \pm 0.2$ & $21542^{\mathrm{abc}} \pm 1317.5$ & $19.6^{\mathrm{GHJ}} \pm 0.4$ \\
\hline Red and White $\times$ above 100 cows & 1422 & $5.6 \pm 0.2$ & $24446^{\mathrm{EC}} \pm 1328.2$ & $21.6^{\mathrm{ClJa}} \pm 0.4$ \\
\hline
\end{tabular}

LECM = lifetime energy-corrected milk yield; DECM = mean lifetime energy-corrected milk yield per milking day; LSM = least square mean.

$a, b, c$ Values within a column, with the same superscripts differ significantly at $P<0.05$.

$A, B, C, D, E, F, G, H, I, J$ Values within a column, with the same superscripts differ significantly at $P<0.01$.

Table 4 Association between strain $\times$ age at first calving and lifetime performance characteristics of the cows

\begin{tabular}{|c|c|c|c|c|}
\hline & & Age at culling (years) & $\operatorname{LECM}(\mathrm{kg})$ & DECM (kg/day) \\
\hline Strain $\times$ age at first calving & $n$ & $\mathrm{LSM} \pm \mathrm{SE}$ & $\mathrm{LSM} \pm \mathrm{SE}$ & $\mathrm{LSM} \pm \mathrm{SE}$ \\
\hline Black and White $\times$ below 2.0 years & 24858 & $5.5^{\mathrm{AB}} \pm 0.1$ & $26824 \pm 352.2$ & $21.0 \pm 0.1$ \\
\hline Black and White $\times$ from 2.0 to 2.6 years & 90459 & $5.7^{\mathrm{AC}} \pm 0.1$ & $26059 \pm 195.5$ & $21.2 \pm 0.1$ \\
\hline Black and White $\times$ above 2.6 years & 16209 & $6.1^{\mathrm{BCDa}} \pm 0.1$ & $23127 \pm 442.8$ & $20.1 \pm 0.1$ \\
\hline Red and White $\times$ below 2.0 years & 747 & $5.2^{\mathrm{D}} \pm 0.2$ & $23545 \pm 1350.3$ & $20.0 \pm 0.4$ \\
\hline Red and White $\times$ from 2.0 to 2.6 years & 2642 & $5.5^{\mathrm{a}} \pm 0.2$ & $22715 \pm 1251.9$ & $20.3 \pm 0.4$ \\
\hline Red and White $\times$ above 2.6 years & 581 & $5.6 \pm 0.2$ & $18439 \pm 1436.7$ & $19.4 \pm 0.4$ \\
\hline
\end{tabular}

LECM = lifetime energy-corrected milk yield; DECM = mean lifetime energy-corrected milk yield per milking day; LSM = least square mean.

${ }^{a}$ Values within a column, with the same superscripts differ significantly at $P<0.05$.

$A, B, C, D$ Values within a column, with the same superscripts differ significantly at $P<0.01$.

Table 5 shows the association between the herd size $\times$ age at first calving subclasses and cow longevity characteristics. The cows in the biggest herds and calved at the earliest age were culled at a significantly $(P=0.0001$ to 0.0407$)$ younger age (5.2 years) than the remaining cows under this study. However, generally, the oldest age at culling (5.9 years) characterised the cows calved first at the oldest age ( $>2.6$ years), regardless of the herd size. This might indicate that the age at first calving was stronger related to the age at culling than the herd size. The herd size $\times$ age at first calving interaction proved to be a significant differentiating factor for LECM and DECM - the difference between the highest and the lowest value amounted to $42 \%$ and $25 \%$, respectively. The lowest values for both LECM and DECM were found for cows in the smallest herds and calved first at the oldest age.

As could be expected, regardless of the strain, the oldest age at culling (9.5 years) was observed in cows culled due to old age (Table 6). The longest lifetime was associated with a high LECM and a relatively low DECM (18.2 to $18.3 \mathrm{~kg}$ ). 
Table 5 Association between herd size $\times$ age at first calving and lifetime performance characteristics of the cows

\begin{tabular}{|c|c|c|c|c|}
\hline & & Age at culling (years) & LECM $(\mathrm{kg})$ & DECM (kg/day) \\
\hline Herd size $\times$ age at first calving & $n$ & $\mathrm{LSM} \pm \mathrm{SE}$ & $\mathrm{LSM} \pm \mathrm{SE}$ & $\mathrm{LSM} \pm \mathrm{SE}$ \\
\hline Below 50 cows $\times$ below 2.0 years & 15146 & $5.5^{\mathrm{abc}} \pm 0.1$ & $23618^{\mathrm{AB}} \pm 787.0$ & $18.7^{\mathrm{ABCDE}} \pm 0.2$ \\
\hline From 50 to 100 cows $\times$ below 2.0 years & 3979 & $5.4 \pm 0.1$ & $25538^{C D} \pm 797.5$ & $20.1^{\mathrm{AFGHIJ}} \pm 0.2$ \\
\hline Above 100 cows $\times$ below 2.0 years & 6480 & $5.2^{\text {Aadefg }} \pm 0.1$ & $26397^{\text {AEFGa }} \pm 795.2$ & $22.7^{\text {BFKLMNO }} \pm 0.2$ \\
\hline below 50 cows $\times$ from 2.0 to 2.6 years & 44016 & $5.6^{\mathrm{A}} \pm 0.1$ & $22509^{\mathrm{EHI}} \pm 713.4$ & $19.0^{\mathrm{GKPQRa}} \pm 0.2$ \\
\hline From 50 to 100 cows $\times$ from 2.0 to 2.6 years & 16709 & $5.6^{f} \pm 0.1$ & $24531^{\mathrm{JK}} \pm 706.2$ & $20.4^{\text {CLPSTbC }} \pm 0.2$ \\
\hline Above 100 cows $\times$ from 2.0 to 2.6 years & 32376 & $5.5^{\mathrm{Bgh}} \pm 0.1$ & $26121^{\mathrm{HLMN}} \pm 689.2$ & $22.8^{\text {DHQSUWX }} \pm 0.2$ \\
\hline Below 50 cows $\times$ above 2.6 years & 8600 & $5.9^{\mathrm{bh}} \pm 0.1$ & $18555^{\text {BCFIJLO }} \pm 844.4$ & $18.2^{\mathrm{IMTUYZa}} \pm 0.3$ \\
\hline From 50 to 100 cows $\times$ above 2.6 years & 3810 & $5.9^{\mathrm{d}} \pm 0.1$ & $20615^{\text {DGKMb }} \pm 895.1$ & $19.6^{\mathrm{NWYŻb}} \pm 0.3$ \\
\hline Above 100 cows $\times$ above 2.6 years & 4380 & $5.9^{\mathrm{Bce}} \pm 0.1$ & $23179^{\mathrm{NOab}} \pm 868.9$ & $21.4^{\text {EJORXZŻc }} \pm 0.3$ \\
\hline
\end{tabular}

LECM = lifetime energy-corrected milk yield; DECM = mean lifetime energy-corrected milk yield per milking day; LSM = least square mean.

$a, b, c, d, e, f, g, h$ Values within a column, with the same superscripts differ significantly at $P<0.05$.

$A, B, C, D, E, F, G, H, I, J, K, L, M, N, O, P, Q, R, S, T, U, W, X, Y, Z, Z$ Values within a column, with the same superscripts differ significantly at $P<0.01$.

Table 6 Association between strain $\times$ culling reason and lifetime performance characteristics of the cows

\begin{tabular}{|c|c|c|c|c|}
\hline & & Age at culling (years) & LECM (kg) & DECM (kg/day) \\
\hline Strain $\times$ culling reasons & $n$ & $\mathrm{LSM} \pm \mathrm{SE}$ & $\mathrm{LSM} \pm \mathrm{SE}$ & $\mathrm{LSM} \pm \mathrm{SE}$ \\
\hline Black and White $\times$ old age & 2276 & $9.5 \pm 0.1$ & $52536 \pm 486.9$ & $20.5 \pm 0.1$ \\
\hline Black and White $\times$ low milk yield & 2905 & $5.1 \pm 0.1$ & $18549 \pm 409.5$ & $18.2 \pm 0.1$ \\
\hline Black and White $\times$ infertility and reproduction problems & 52064 & $5.7 \pm 0.1$ & $25007 \pm 96.2$ & $20.8 \pm 0.1$ \\
\hline Black and White $\times$ udder diseases & 20336 & $5.6 \pm 0.1$ & $24102 \pm 152.2$ & $20.8 \pm 0.1$ \\
\hline Black and White $\times$ legs diseases & 13701 & $5.5 \pm 0.1$ & $24064 \pm 181.9$ & $21.3 \pm 0.1$ \\
\hline Black and White $\times$ nutritive and metabolic diseases & 10396 & $5.2 \pm 0.1$ & $21299 \pm 222.3$ & $21.2 \pm 0.1$ \\
\hline Black and White $\times$ respiratory system diseases & 884 & $5.1 \pm 0.1$ & $20549 \pm 785.2$ & $21.1 \pm 0.2$ \\
\hline Black and White $\times$ infectious diseases & 157 & $5.2 \pm 0.2$ & $22288 \pm 1725.6$ & $22.1 \pm 0.5$ \\
\hline Black and White $\times$ accidents & 16395 & $5.3 \pm 0.1$ & $22251 \pm 166.5$ & $21.1 \pm 0.1$ \\
\hline Black and White $\times$ other & 12412 & $5.5 \pm 0.1$ & $22721 \pm 190.1$ & $20.7 \pm 0.1$ \\
\hline Red and White $\times$ old age & 71 & $9.5 \pm 0.3$ & $47542 \pm 1937.6$ & $18.3 \pm 0.6$ \\
\hline Red and White $\times$ low milk yield & 148 & $4.8 \pm 0.2$ & $15971 \pm 1356.6$ & $17.3 \pm 0.4$ \\
\hline Red and White $\times$ infertility and reproduction problems & 1529 & $5.5 \pm 0.1$ & $21702 \pm 453.4$ & $19.0 \pm 0.1$ \\
\hline Red and White $\times$ udder diseases & 677 & $5.5 \pm 0.1$ & $21425 \pm 640.7$ & $19.1 \pm 0.2$ \\
\hline Red and White $\times$ legs diseases & 456 & $5.3 \pm 0.1$ & $20835 \pm 766.4$ & $19.8 \pm 0.2$ \\
\hline Red and White $\times$ nutritive and metabolic diseases & 266 & $5.1 \pm 0.1$ & $18959 \pm 994.1$ & $19.3 \pm 0.3$ \\
\hline Red and White $\times$ respiratory system diseases & 20 & $5.2 \pm 0.5$ & $20888 \pm 3574.1$ & $20.8 \pm 1.1$ \\
\hline Red and White $\times$ infectious diseases & 2 & $3.2 \pm 1.5$ & $9656 \pm 11439.3$ & $26.9 \pm 3.5$ \\
\hline Red and White $\times$ accidents & 394 & $5.1 \pm 0.1$ & $19004 \pm 828.1$ & $19.3 \pm 0.3$ \\
\hline Red and White $\times$ other & 407 & $5.2 \pm 0.1$ & $19681 \pm 818.3$ & $19.0 \pm 0.3$ \\
\hline
\end{tabular}

LECM = lifetime energy-corrected milk yield; DECM = mean lifetime energy-corrected milk yield per milking day; LSM = least square mean.

However, the differences between the age at culling, LECM and DECM of cows from various classes of strain $\times$ culling reason were not significant.

The associations between the herd size $\times$ culling reason subclasses and cow longevity characteristics as well as between the age at first calving $\times$ culling reason subclasses and cow longevity characteristics were given in Supplementary Table S1.

\section{Discussion}

Although the potential lifespan of cattle can exceed 20 years, cows used by the dairy industry usually do not live longer than 6 years (Rushen and de Passillé, 2013). This was also confirmed by the results of the present study. The longest lifespan, amounting to 9.5 years on mean, and the highest LECM, exceeding $50000 \mathrm{~kg}$, characterised the cows culled due to old age. Although it indicates a high potential both for longevity and lifetime productivity, the number of cows culled due to old age was very low. The results of this study are similar to the age at culling ( 5.1 to 5.59 years) of highyielding HF cows in big Polish herds as determined by Nienartowicz-Zdrojewska et al. (2012), Oler et al. (2012) and Jankowska et al. (2014) through the analyses of data from 1997-2007, 2006-11 and 2000-12, respectively. Performed analyses did not reveal significant differences in the longevity 
between both studied strains of HF cows. However, significantly higher DECM of BW strain with only slightly higher age at culling resulted in a highly significant advantage of this strain as regards LECM.

Decisions on cow culling mainly depend on economic factors. Monti et al. (1999) argued that dairy cows can be used profitably up to the age of over 7 years, but nowadays such longevity in herds of high-yielding cows is rather rare. According to de Vries (2013), due to the many intrinsic (health, milk performance, reproductive status) and extrinsic (replacement heifers availability, parlour capacity, land availability, prices) factors affecting dairy cow longevity, only complex calculations referring to a specific situation are justified. Results obtained from the linear programming model by de Vries (2013) indicate that cows with a higher milk yield should be kept in the herd longer. However, these results also confirm that cow longevity depends largely on the external economic conditions. For example, the extension of cow productive life is advisable at high costs of feeds and replacement heifers and at low milk prices. Also Nor et al. (2015) claimed that the optimal percentage of heifer retention is strictly related to the specificity of a particular herd and farm. They evoke the example of the Netherlands where farming and economic conditions generally do not promote rearing all heifers as dairy cow replacements. Moreover, Hadley et al. (2006) suggested that the heifer replacement rate may be affected by the interaction between the cow culling age, the culling season and the milk price. Their research indicates that cows calving in the summer and autumn are culled less often than those calving in the spring. The economically optimal decisions on cow culling and its replacement with a heifer can be supported by many computer models developed in the last 30 years (e.g. Kristensen, 1989; Mourits et al., 1999; Cha et al., 2010). The modelling technique allows for considering the variability of production and economic parameters and for evaluating the consequences of different herd management strategies.

The results of our research indicate that the shortest longevity but the highest lifetime milk yield was typical for cows maintained in the biggest herds (>100 cows) and first calved at the earliest age ( $<2$ years). A similar relationship between the herd size and the length of Polish HF cow productive life was also found by Jankowska et al. (2014). Curran et al. (2013) found a positive impact of early age at first calving on HF cow longevity and lifetime performance, especially when associated with the increased frequency of milking up to three times a day. They suggest that more frequent milking is often practiced in free-stall system, which favours slightly longer lifetime days in milk. Sawa and Bogucki (2010) found that among cows culled in 1996, those that calved first at the age of 26.1 to 28.0 months were used for the longest period of time (2.9 years) but among the cows culled 12 years later, the longest productive life, amounting to 4.2 years, was achieved by cows that calved first at the age of $\leqslant 22.0$ months. It could be explained by the fact that in the last 20 years a share of HF genes in the population of Polish dairy cows was constantly increasing. Owing to a high growth potential, HF heifers can probably reach the body weight and body condition score desired for breeding at a younger age (Coffey et al., 2006). Therefore, some authors claim that they can be bred earlier than advised so far without a detrimental effect on their lifetime productivity and even a positive effect on the lifetime economic efficiency. Although the reduced age at first calving (about 22 months) usually negatively affects the first lactation milk yield, the lifetime production and the overall dairy herd profitability is increased (Mourits et al., 1999; Zavadilová and Štípková, 2013). Cows calving first earlier can also have an advantage in terms of reproductive performance. The findings of Zavadilová and Štípková (2013) indicated that cows of a late age at first calving (33 to 46 months) expressed worse fertility at the first lactation and a shorter productive life than those calved first earlier.

The present study revealed that just like in many other countries the majority of HF cows in Poland were culled mainly due to reproduction problems and udder diseases. However, a marked upward trend in the frequency of disposal due to the above-mentioned reasons is observed, since in 1997-2007 they accounted for only about $30 \%$ of cullings (Nienartowicz-Zdrojewska et al., 2012), which was much lower value compared with our estimate in 2012 $(55.1 \%)$. The increase in the frequency of culling because of infertility, reproduction problems and udder diseases was accompanied by a decline in the frequency of culling because of low milk yield (Oler et al., 2012; Jankowska et al., 2014). The changes in the culling pattern of HF cows in Poland were caused by the constant selecting for milk performance and the associated increasing intensity of cow use. According to Roche (2006) and Ahlman et al. (2011), the frequency of udder diseases and reproductive system diseases is to a large extent related to the daily milk yield, which in turn is highly dependent on the nutrition level.

In the last few years, the milk performance of Polish HF cows did not change significantly. Similarly to the results of the present study, the mean yield of the cows culled in 2014 was $20 \mathrm{~kg}$ of DECM and $23600 \mathrm{~kg}$ of LECM for BW, and $19 \mathrm{~kg}$ of DECM and $20600 \mathrm{~kg}$ of LECM for RW (own calculations, based on PFCBDF, 2015). This suggests that there were no environmental or economic factors which would force dairy farmers to change their strategy for breeding and production. It might be interesting to analyse how the withdrawal of milk quota in 2015 influences the decisions of dairy farmers. Currently observed effects in Poland are the increase in total milk production, and consequently a considerable decline in its prices.

In order to increase the survival and longevity of $\mathrm{HF}$ cows 2- and 3-breed, cross-breeding with other dairy cow breeds (Ayrshire, Brown Swiss, Normande, Montbeliarde, Danish Red, Scandinavian Red) of a lower genetic potential for milk production, but with better functional traits is suggested (Heins et al., 2006; Sørensen et al., 2008; Blöttner et al., 2011). However, this option seems to be attractive only for a small number of Polish dairy farmers who do not use cows very intensively. It will not be of interest to those who still 
want to improve the productivity of their herds by replacing the culled cows with heifers of a higher genetic potential for milk production. An additional argument for a faster turnover is that HF bulls, both Polish and foreign, are assessed using the modified selection indexes, which to a considerable extent promote functional traits. Genetic progress, also with regard to functional traits, can be particularly enhanced through the increasingly widespread use of genomic selection. The systematic introduction of heifers with higher breeding value for functional traits should result in the decreased frequency of involuntary cullings and a longer cow productive life. However, independently of the breeding activities to increase the genetic potential for longevity, the decrease of the involuntary disposal in high-yielding dairy herds can be achieved by providing proper cow management. It includes a balanced nutrition and well-organised reproduction, so as to ensure an adequate animal welfare (Royal Society for the Prevention of Cruelty to Animals, 2011). The fulfilment of all these requirements entails high expenditure. This, in turn, leads to a question about the economically optimal cow lifetime and milk production intensity. Striving to increase milk performance at the expense of shortening cow productive life or incurring high expenses aimed at the extension of the productive life of high milk yielding cows might prove unprofitable. Therefore, less intensive use of cows resulting in a lower milk yield but a longer time of its production, can sometimes assure higher profits. But it should be strongly emphasised that the economically optimal milk production intensity always ought to be adopted for the conditions of a particular herd.

Concluding, the length of the productive life and the lifetime performance depend on many factors and interactions between them. In Poland, as in many other countries, the intensification of milk production without the adequate attention to animal welfare significantly cut the $\mathrm{HF}$ cow longevity. Recently, breeding activities to genetically increase the cow robustness have been undertaken. At the same time, a considerable efforts to improve cow housing conditions have also been made. They can significantly contribute to extending the productive life, even with the intensive production. However, taking into account the expenditure associated with the proper management of high-yielding cows, the answer to the question about the economically optimal longevity is not unequivocal. It appears that less intensive, more sustainable use of dairy herd can sometimes result in a higher overall profitability of the dairy operation. Thus, the quality of dairy herd management should most probably be measured not by the cow's mean milk performance, not even by the cow's lifetime milk performance, but rather by the lifetime profit from the cow.

\section{Acknowledgements}

This study was carried out using data provided by the Polish Federation of Cattle Breeders and Dairy Farmers in Warsaw (PFCBDF); Contract No. 47/2013 between PFCBDF and the University of Agriculture in Krakow; the purchase of the data was financed from the funds for statutory activity, by the Ministry of Science and Higher Education in Poland.

\section{Supplementary material}

For supplementary material/s referred to in this article, please visit http://dx.doi.org/10.1017/S1751731116001348

\section{References}

Ahlman T, Berglund B, Rydhmer L and Strandberg E 2011. Culling reasons in organic and conventional dairy herds and genotype by environment interaction for longevity. Journal of Dairy Science 94, 1568-1575.

Axelsson HH 2013. Breeding for sustainable milk - production from nucleus herds to genomic data. PhD thesis, Swedish University of Agricultural Sciences, Uppsala, Sweden.

Blöttner S, Heins BJ, Wensch-Dorendorf M, Hansen LB and Swalve HH 2011. Brown Swiss $\times$ Holstein crossbreds compared with pure Holsteins for calving traits, body weight, backfat thickness, fertility, and body measurements. Journal of Dairy Science 94, 1058-1068.

Cha E, Hertl JA, Bar D and Gröhn YT 2010. The cost of different types of lameness in dairy cows calculated by dynamic programming. Preventive Veterinary Medicine $97,1-8$.

Coffey MP, Hickey J and Brotherstone S 2006. Genetic aspects of growth of Holstein-Friesian dairy cows from birth to maturity. Journal of Dairy Science 89, 322-329.

Curran RD, Weigel KA, Hoffman PC, Marshall JA, Kuzdas CK and Coblentz WK 2013. Relationships between age at first calving; herd management criteria; and lifetime milk, fat, and protein production in Holstein cattle. The Professional Animal Scientist 29, 1-9.

De Vries A 2013. Cow longevity economics: the cost benefit of keeping the cow in the herd. Proceedings of the Conference 'Cow Longevity Conference', 28-29 August, Hamra Farm/Tumba, Sweden, pp. 22-52.

Hadley GL, Wolf CA and Harsh SB 2006. Dairy cattle culling patterns, explanations, and implications. Journal of Dairy Science 89, 2286-2296.

Heinrichs AJ and Heinrichs BS 2011. A prospective study of calf factors affecting first-lactation and lifetime milk production and age of cows when removed from the herd. Journal of Dairy Science 94, 336-341.

Heins BJ, Hansen LB and Seykora AJ 2006. Production of pure Holsteins versus crossbreds of Holstein with Normande, Montbeliarde, and Scandinavian Red. Journal of Dairy Science 89, 2799-2804.

International Committee for Animal Recording 2012. International agreement of recording practices. Retrieved on 5 May 2013 from http://www.icar.org.

Jankowska M, Sawa A and Kujawska J 2014. Effect of certain factors on the longevity and culling of cows. Acta Scientiarum Polonorum Zootechnica 13, 19-30.

Kristensen AR 1989. Optimal replacement and ranking of dairy cows under milk quotas. Acta Agriculturae Scandinavica 39, 311-318.

Miglior F, Muir BL and Van Doormaal BJ 2005. Selection indices in Holstein cattle of various countries. Journal of Dairy Science 88, 1255-1263.

Monti G, Tenhagen B-A and Heuwieser W 1999. Culling policies in dairy herds. A review. Journal of Veterinary Medicine Series A 46, 1-11.

Mourits MCM, Huirne RBM, Dijkhuizen AA, Kristensen AR and Galligan DT 1999. Economic optimization of dairy heifer management decisions. Agricultural Systems 61, 17-31.

Nienartowicz-Zdrojewska A, Różańska-Zawieja J, Dymarski I, Konieczka A and Sobek Z 2012. Analysis of productivity, longevity and culling causes of Jersey and Polish Holstein-Friesian (PHF) cows. African Journal of Biotechnology 11, 14110-14115.

Nor NM, Steeneveld W, Mourits MCM and Hogeveen H 2015. The optimal number of heifer calves to be reared as dairy replacements. Journal of Dairy Science 98, 861-871.

Oler A, Sawa A, Urbańska P and Wojtkowiak M 2012. Analysis of longevity and reasons for culling high yielding cows. Acta Scientiarum Polonorum Zootechnica $11,57-64$.

Oltenacu PA and Broom DM 2010. The impact of genetic selection for increased milk yield on the welfare of dairy cows. Animal Welfare 19 (suppl.), 39-49. 
Adamczyk, Makulska, Jagusiak and Węglarz

Polish Federation of Cattle Breeders and Dairy Farmers in Warsaw (PFCBDF) 2015. Wyniki oceny wartości użytkowej krów mlecznych. Retrieved on 21 December 2015 from http://www.pfhb.pl/.

Pritchard T, Coffey M, Mrode R and Wall E 2013. Genetic parameters for production, health, fertility and longevity traits in dairy cows. Animal 7, 34-46. Roche JR 2006. The effect of nutritional management of the dairy cow on reproductive efficiency. Animal Reproduction Science 96, 282-296.

Royal Society for the Prevention of Cruelty to Animals 2011. RSPCA welfare standards for dairy cattle. Retrieved on 12 April 2016 from http://www.rspca.org.uk.

Rushen J and de Passillé AM 2013. The importance of improving cow longevity. Proceedings of the Conference 'Cow Longevity Conference', 28-29 August, Hamra Farm/Tumba, Sweden, pp. 3-21.

SAS Institute Inc. 2008. SAS/STAT ${ }^{\circledR} 9.2$ User's Guide. SAS® Publishing, Cary, NC, USA.

Sawa A and Bogucki M 2010. Effect of some factors on cow longevity. Archiv Tierzucht 53, 403-414.
Sawa A and Krężel-Czopek S 2009. Effect of first lactation milk yield on efficiency of cows in herds with different production levels. Archiv Tierzucht 52, 7-14.

Sjaunja LO, Baevre L, Junkkarinen L, Pedersen J and Setala J 1990. A Nordic proposal for an energy corrected milk (ECM) formula. Proceedings of the 27th Biennial Session of the International Committee for Animal Recording (ICAR), 2-6. July, Paris, France, pp. 156-192.

Sørensen MK, Norberg E, Pedersen J and Christensen LG 2008. Invited review: crossbreeding in dairy cattle: a Danish perspective. Journal of Dairy Science 91 4116-4128.

Thornton PK 2010. Livestock production: recent trends, future prospects. Philosophical Transactions of the Royal Society B 365, 2853-2867.

Zavadilová $L$ and Štípková M 2013. Effect of age at first calving on longevity and fertility traits for Holstein cattle. Czech Journal of Animal Science 58, 47-57.

Zavadilová L and Zink V 2013. Genetic relationship of functional longevity with female fertility and milk production traits in Czech Holsteins. Czech Journal of Animal Science 58, 554-565. 